\title{
$\mathrm{Ni}$ 電極ペーストのペースト分散性と Ni 粉体特性が焼結特性に与える影響
}

\author{
上山竜祐·上山 守 + 河本邦仁* ·栗林 清**
}

大研化学工業(株)製造技術部電極グループ，536-0011 大阪府大阪市城東区放出西 2-7-19

*名古屋大学大学院工学研究科物質化学専攻, 464-0814 愛知県名古屋市千種区不老町

**帝京科学大学理工学部環境マテリアル学科, 409-0193 山梨県北都留郡上野原町八ツ沢

\section{Dependence of Sintered Electrode Ni Paste on Dispersed Ni Paste and Ni Powder Properties}

\author{
Ryosuke UEYAMA, Tamotsu UEYAMA ${ }^{\dagger}$, Kunihito KOUMOTO* and Kiyoshi KURIBAYASHI** \\ Daiken Chemical Industry Corporation Limited, 2-7-19, Hanaten-Nishi, Joto-ku, Osaka-shi 536-0011 \\ *Department of Applied Chemistry, Graduate School of Engineering, Nagoya University, Furo-cho Chikusa-ku, Nagoya-shi $464-8603$ \\ **Department of Materials, Teikyo University of Science and Technology, Yatuzawa, Uenohara-machi, Kitatsuru-gun, Yamanashi 409-0193
}

\begin{abstract}
We evaluated the characteristics of $\mathrm{Ni}$ paste used for internal electrodes of multilayer ceramic chip capacitors (MLCs). The effects of dispensability of $\mathrm{BaTiO}_{3}$ powder in $\mathrm{Ni}$ paste and $\mathrm{Ni}$ powder properties on sintering characteristics of electrode films were studied. The experimental results revealed that an improvement of dispensability of $\mathrm{BaTiO}_{3}$ suppressed shrinkage of the films. It was observed that properties of $\mathrm{Ni}$ powder influenced on the shrinkage of electrode films, i.e., Ni powder prepared by the WCP method showed a higher shrinkage than that of the powder made by the CVD method. The similar results were observed on the surface microstructure of sintered ellectrode films by SEM measurements.
\end{abstract}

[Received September 6, 2000; Accepted December 11, 2000]

Key-words : Ni paste, $\mathrm{BaTiO}_{3}$, Dispersion, Multilayer ceramic devices, Sintering properties

\section{1. 緒 言}

MLCの薄層化, 高積層化が進むに伴い，これに使用する内 部電極材料の低コスト化が強く求められている.これを受けて コストダウンの観点から, 従来のパラジウム $(\mathrm{Pd})$ をニッケ ル (Ni) に置き換えたものが盛んに研究されている1) 8).

通常, 積層セラミックコンデンサ (MLC) に使用する内部 電極塗料 (ペースト) には, 内部電極 (金属) と誘電体層（セ ラミックス）との接合強度を高める目的で, $\mathrm{BaTiO}_{3}$ など超 微粉体を共材と称して添加している.

また，MLCの暁成では，セラミックスと電極との同時暁成 を必要としているため, それらの焼成収縮曲線をマッチングさ せるためにも共材忙必要不可欠である.この焼成収縮率を制御 する要因として，先に著者らは金属粉体の凝集粒子の解粒と均 一分散が重要な因子であることを報告した ${ }^{9}$ 。また，共材添加 量の影響が大さいことも報告した10)。しかし，筶成収縮率に 影響を与える大きな要因の一つとして, Niペーストの共材微 粒子の均一分散性や $\mathrm{Ni}$ 粉体の持つ特性, つまり製造方法の違 いからくる粒度分布や表面活性の違いなどの粉体特性が極めて 重要な因子になっていると考えられる.

そこで本研究では, 凝集粒子を解粒した湿式化学 (wet chemical process, 以下 WCP と略す) 法で合成した Ni粉体 及び気相化学析出法 (chemical vapor deposition, 以下 CVD 法と略ず）で合成した Ni 粉体を用い共材の分散性の違いと Ni 粉体の製造方法の違いが $\mathrm{Ni}$ 電極膜の燒結特性にどのように影 響するのか検討したので報告する。

\section{2. 実験方法}

本研究では, 高積層コンデンサ内部電極を目的に開発した

\footnotetext{
†現在：329-3446 板木県那須郡那須町大字沼野井 629-81

Now with 629-81, Numanoi, Oaza Nasu-machi, Nasu-gun, Tochigi $329-3446$
}

WCP 法で調整し解粒処理を施した Ni 粉体を用いた ${ }^{11)}$ 。具体 的には，硫酸 $\mathrm{Ni}$ に苛性ソーダ $(\mathrm{NaOH})$ を反忘させ水酸化 $\mathrm{Ni}$ を合成しそれをヒドラジン $\left(\mathrm{N}_{2} \mathrm{H}_{4}\right)$ で還元した．この粉体を 解粒処理して ${ }^{12)}$, 平均粒径が $0.6 \mu \mathrm{m}$ の $\mathrm{Ni}$ 粉体を得た.

CVD 法による $\mathrm{Ni}$ 粉体は, 市販品の平均粒径 $0.6 \mu \mathrm{m}$ の Ni 粉 体を用い，同様に解粒処理した。すなわち，WCP 法と CVD 法の Ni 粉体の分散性は解粒処理によりほぼ同等なものとし た.

WCP 法で合成した Ni 粉体とCVD法で合成した Ni 粉体在 解粒処理した後, 上記 2 種類の Ni 粉体 $55 \mathrm{~g}$ にエチルセルロー ス（バインダー）を $2.2 \mathrm{~g}$ とタピネオール（溶剤）を $42.8 \mathrm{~g}$ 混 合し，更に共材として水熱合成法により合成した $\mathrm{BaTiO}_{3}$ (堺 化学工業製， $0.1 \mu \mathrm{m}$ 粉体）を $\mathrm{Ni}$ 粉体に対して各 10 mass \% 添 加し，雷かい機で混鍊することにより $\mathrm{Niペーストをそれぞれ}$ 作製した.

ペーストの特性については, グリーン密度と焼成収縮率を測 定しペーストの分散性と Ni 電極膜の緻密性との関係を調べる ことで評価した。

グリーン密度は，以下の手順で求めた。まず，ペットフィル ム上にアプリケータで約 $200 \mu \mathrm{m}$ 厚の $\mathrm{Ni}$ 電極膜を形成し $100^{\circ} \mathrm{C}$ で $1 \mathrm{~h}$ 乾燥後, ペットフィルムから Ni 電極膜を剥がし, ポン チを用いて13 mm の円盤に剞り拔きマイクロメーターで愿み を，なた精度が 1/1000 mg の精密化学天秤で質量を測定し質 量/体積からグリーン密度を計算で求めた。

焼結特性は，以下の手順で電極膜の㫩成収縮率を測定するこ とで求めた。具体的には，グリーン密度と同様な方法で作製し た200 $\mu \mathrm{m}$ 厚の $\mathrm{Ni}$ 電極膜を円盤型で打ち抜きこの試料を $97 \%$ $\mathrm{N}_{2}+3 \% \mathrm{H}_{2}$ の還元䨌囲気中で每分 $3^{\circ} \mathrm{C}$ で昇温し, $600 \sim 1000^{\circ} \mathrm{C}$ までの温度範囲で $2 \mathrm{~h}$ 保持する温度プログラムによって焼成し た，次いでこの焼成した円盤試料の外径寸法を計測顕微鏡で測 定し, 焼成前後の外径寸法から焼成収縮率を計算で求めた。各 
焼成温度に招ける焼成後の表面構造は, 走査型電子顕微鏡 （SEM；日本電子製，JSM-6100 型）を用いて観察した。

\section{3. 結果及び考察}

$3.1 \mathrm{Ni}$ ペースト中の共材微粒子の分散性が焼成収縮率に与 える影響

図１は, $\mathrm{Ni}$ ペースト中の共材微粒子の分散状態を模式図化 したものである。共材の分散状態は，図 1 (b)に示すように $\mathrm{Ni}$ 粒子間のスリーポケットに入りこみかつ均一に分散されている ことが理想で岁る。共材微粒子が均一に分散されていない場 合，つまり図 1(a)に示したように一部の Ni 粒子同士が密接し ているような場合には，比較的低温 $\left(600 \sim 1000^{\circ} \mathrm{C}\right)$ 領域でそ れが容易に相互拡散する。このため， Ni 電極膜は焼結しやす くなると考えられる.しかし，図 1(b)のように共材が均一に 分散されていれば，共材が Ni 粒子間のスリーポケットに入り $\mathrm{Ni}$ の暁結を妨げる。すなわち，低温 $\left(600 \sim 1000^{\circ} \mathrm{C}\right)$ 領域で の燒結が抑制されると考えられる.

そこで，Niペースト中の共材の分散性が焼成収縮率にどの ように影響するのかを検討した。

共材の分散性の違いについては，2 種類の同一粒度分布をも つWCP 法で合成した解粒処理をした Ni 粉体を用い Niペース トを作製する段階での混練時間だけを変化させた。つをり， ペーストの練り状態を良くしたものとそうでないものとした。

まず，共材の分散度合いをグリーン密度で評価した。その結 果，共材微粒子が 10 mass\%添加したときの分散性が悪い Ni ペーストのグリーン密度は, $5.0 \mathrm{~g} / \mathrm{cm}^{3}$ であり分散性が良い $\mathrm{Ni}$ ペーストのグリーン密度は $5.3 \mathrm{~g} / \mathrm{cm}^{3}$ であった。

このことより $\mathrm{Ni}$ ペースト中の共材は混練時間を上げること によって Ni 粒子同士のスリーポケットに入り込みグリーン密 度を向上させたものと考光られる。これは先に著者らが共材添 加量とグリーン密度の関係で示した結果とよく一致してい た ${ }^{10)}$.

また，共材の分散状熊をSEMによって観察した．その結果 を図 2 (a)，（b) に示す。. SEM 写真加ら共材混練時間を十分長 くした Niペースト（図 2(b) )では共材がほぼ均一に分散され ているのが観察されるが，共村の混練時間が不十分な Niペー ストは図 2 (a)に示したように共材が一個所にまとまって存在 している所が見られる，すなわち，共材の分散性の良し悪しが $\mathrm{Ni}$ 電極膜の微構造に大きな違いをもたらしていることが観察 された。

そこで，この分散性の違いが焼結特性にどのように影響を及 ぼしているのかを確かめる目的で，共材の分散性が異なる図 2 (a)，(b)の電極膜について焼成収縮率を測定した。 その結果 を図 3 に示す。図より，ペーストの混練時間を長くして共材を 十分均一に分散させた $\mathrm{Ni}$ ペースト膜（図中包）は，分散が 不十分な Niペースト膜（図中○印）に比べて全体的に焼成収 縮率が小さいことが分かった。

このことより，共材 $\left(\mathrm{BaTiO}_{3}\right)$ が均一に分散されず一個所 に偏って存在する場合には，隣接する $\mathrm{Ni}$ 粒子同士が焼結する

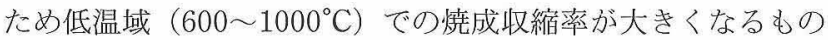
と考えられる.

一方，共材の $\mathrm{BaTiO}_{3}$ が均一に分散されている場合には，Ni 粒子間に共材が入り込み， $\mathrm{Ni}$ 粒子を覆うため， Ni 粒子間の相 互拡散を妨げ，Ni 粒子同士の焼結を阻害する。このため，焼 成収縮率が小さくなるものと考えられる。 したがって, 焼成収 縮率を制御する要因として，共材の分散性が重要であることが 明らかである。

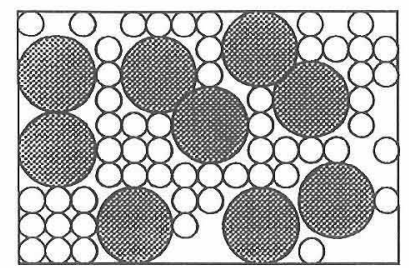

(a)

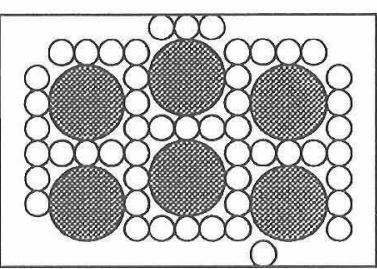

(b)
Fig. 1. Typical model of dispersion state of $\mathrm{BaTiO}_{3}$ ultrafine powder in $\mathrm{Ni}$ electrode films.

(a) Inhomogeneous dispersion, (b) homogeneous dispersion. (a)

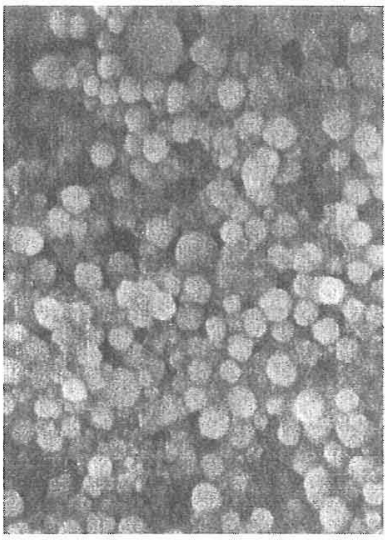

(b)

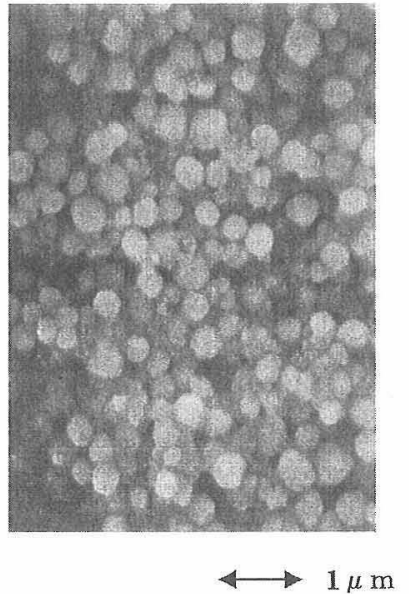

Fig. 2. SEM photographs of Ni electrode films with $\mathrm{BaTiO}_{3}$ ultrafine powder.

(a) Inhomogeneous dispersion, (b) homogeneous dispersion.

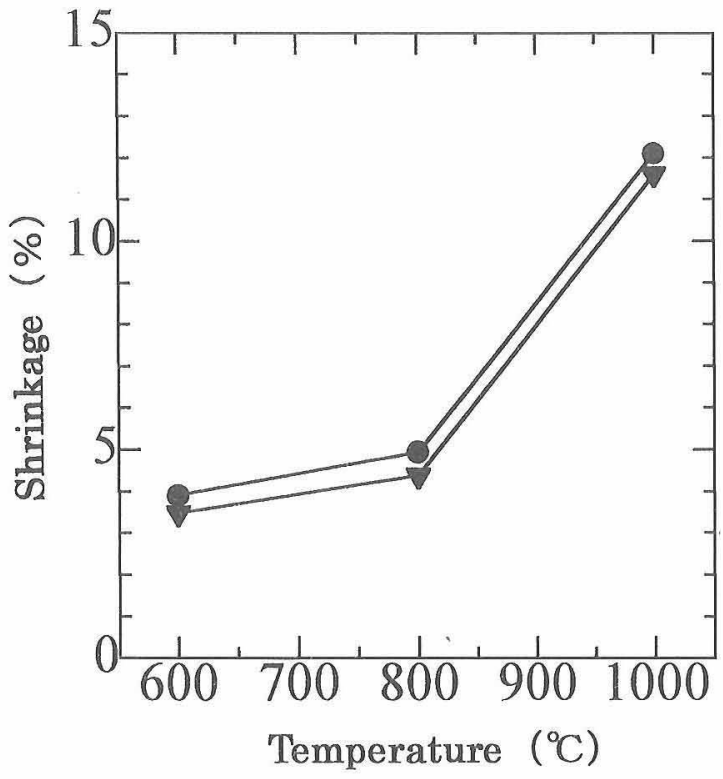

Fig. 3. Dependence of shrinkage on dispersion state of $\mathrm{BaTiO}_{3}$ ultrafine powder.

Inhomogeneous dispersion, $\nabla$ homogeneous dispersion. 
3.2 共材の分散状態が焼結体表面構造に与える影響 $\mathrm{Ni}$ 電極膜を作製し, 共材の分散性が電極膜表面の微細構造, つまり Ni 粒子の焼結状態に与える影響を SEM で観察した。 その結果を図 4 に示した. $800^{\circ} \mathrm{C} て ゙$ 燒結した電極膜では，共材 の分散性の違いによる影響が見られた。すなわち，共材の十分 均一な分散により，600 $800^{\circ} \mathrm{C} て ゙ の ~ N i$ 粒子同士の焼結が適度 に抑制されていることが観察された。

このことは，暁成収縮率からも予測したが，共材の均一分散 が低温（600 $\left.1000^{\circ} \mathrm{C}\right)$ 域での焼結抑制に効果を及ぼしている ことを，SEM 観察からも裏付性たものと考えられる。

\section{$3.3 \mathrm{Ni}$ 粉体特性が焼成収縮率に与える影響}

低温焼成領域 $\left(600 \sim 1000^{\circ} \mathrm{C}\right)$ での焼成収縮率を抑制するも う一つの要因として，Niの粒径依存性があげられる。つま り, $0.1 \mu \mathrm{m}$ 以下の超微粒子の存在は低温領域での焼結を促進

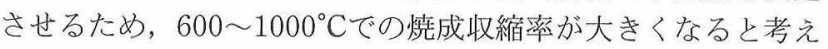
られる. しかし, 高温領域 $\left(1200 \sim 1350^{\circ} \mathrm{C}\right)$ では, 粒径依存 性はほとんど消失し, Ni 電極膜のグリーン密度だけが最終焼 成収縮率を支配するするものと考えられる.

そこで，WCP 法で合成した粒径分布がシャープな Ni 粉体
と, 粗大粒子が混在する広い粒径分布をもった Ni 粉体を用い て電極膜を作製し， $600 \sim 1000^{\circ} \mathrm{C} に お け る$ 焼成収縮率を測定す ることにより粒径依存性を検討した。 なた，CVD 法により合 成した，粗粒を含む同じような広い粒径分布の Ni 粉体につい ても焼成収縮率を測定し，粉体の製法による違いが焼成収縮率 におよぼす影響について検討した。

表 1 は, 検討した 3 種類の $\mathrm{Ni}$ 粉体の粉体特性を示した。 た，これらの粉体のSEM 写真と粒度分布の測定結果を図 5 に 示した。WCP 法で合成した粒度分布の幅のひろい Ni 粉体

Table 1. Properties of Ni Powders

\begin{tabular}{cccc}
\hline Sample name & $\begin{array}{c}\text { Specific Surface } \\
\text { Area }\left(\mathrm{m}^{2} \mathrm{~g}^{-1}\right)\end{array}$ & $\begin{array}{c}\text { Average Particle } \\
(\mu \mathrm{m})\end{array}$ & $\begin{array}{c}\text { Size } \\
\left(\mathrm{gcm}^{-3}\right)\end{array}$ \\
\hline (a) & 1.58 & 0.6 & 3.03 \\
(b) & 1.58 & 0.9 & 3.13 \\
(c) & 1.58 & 0.9 & 3.6 \\
\hline
\end{tabular}

(a) Ni Powder Synthesized by WCP Method, (b) Ni Powder Synthesized by WCP Method, (c) Ni Powder Synthesized by CVD Method
(1) $600^{\circ} \mathrm{C}$

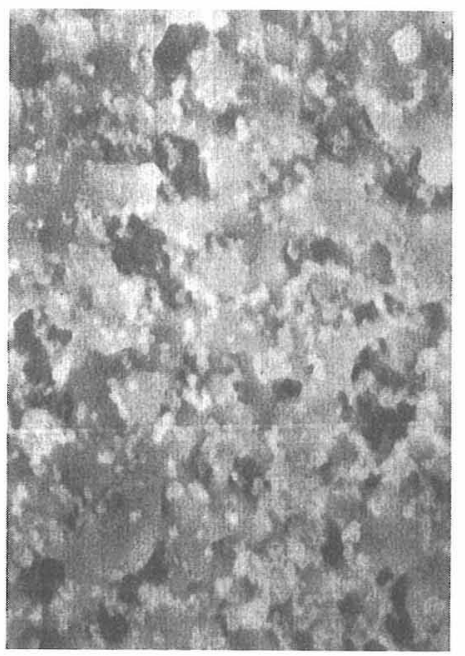

(a)
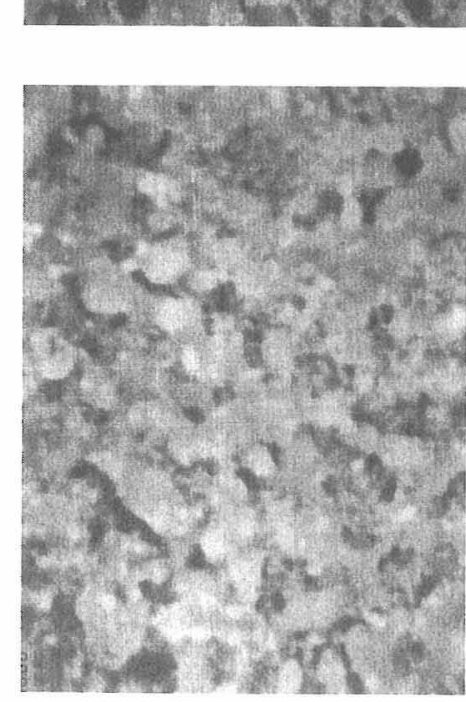

(2) $800^{\circ} \mathrm{C}$
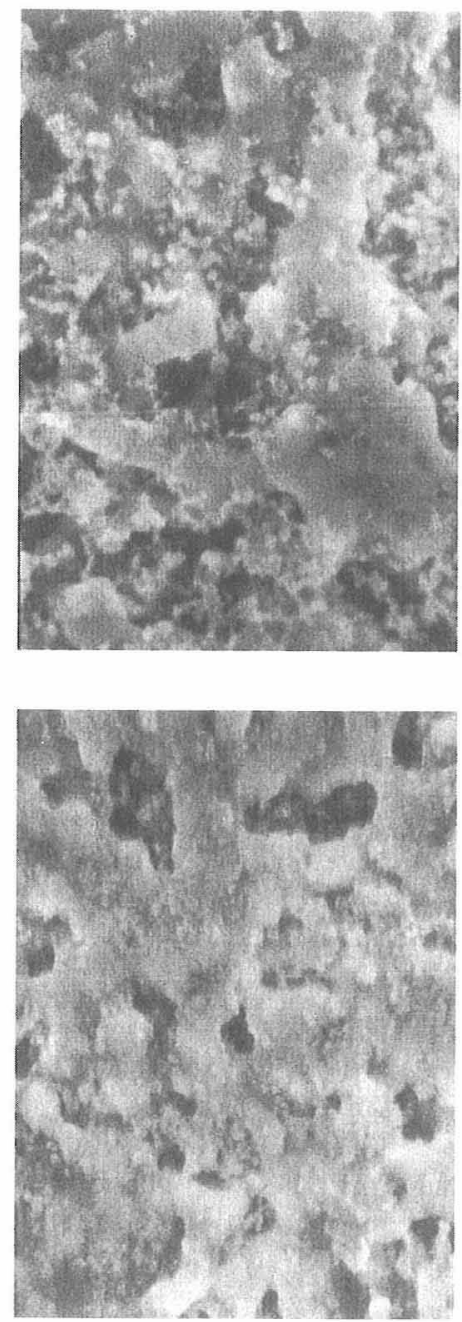

(3) $1000^{\circ} \mathrm{C}$
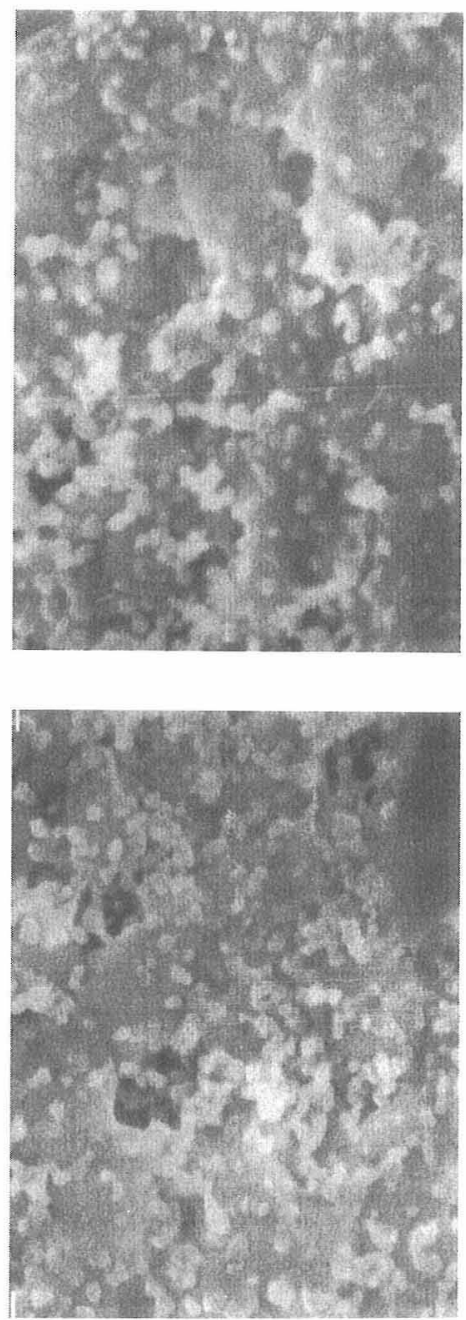

$\longleftrightarrow 1 \mu \mathrm{m}$

Fig. 4. SEM photographs of Ni electrode films sintered with various dispersion state of $\mathrm{BaTiO}_{3}$ ultrafine powder. (a) Inhomogeneous dispersion, (b) homogeneous dispersion. 
(a)
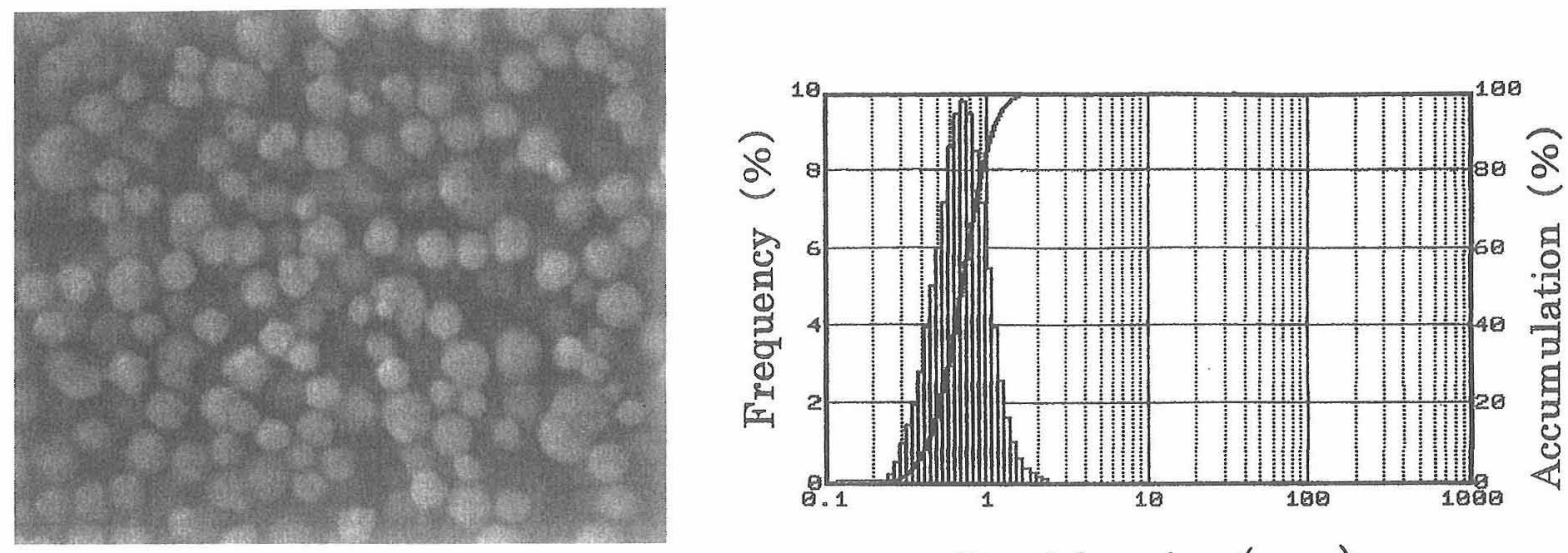

Particle size $(\mu \mathrm{m})$

(b)
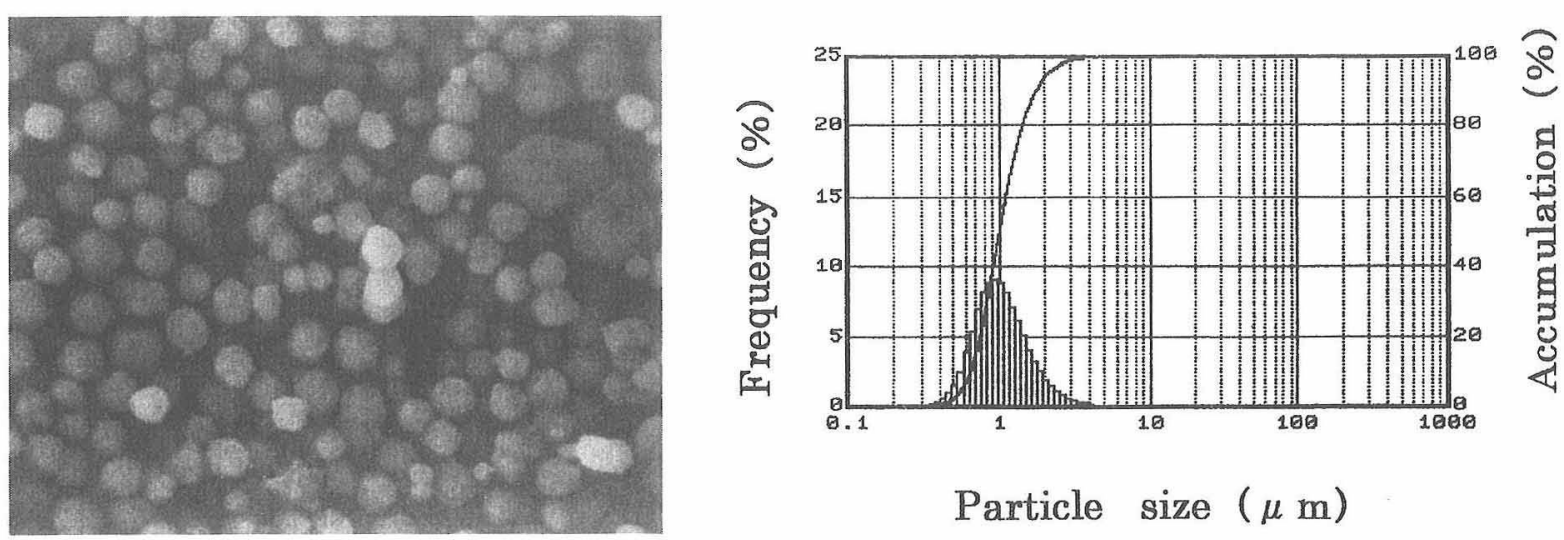

Particle size $(\mu \mathrm{m})$

(c)
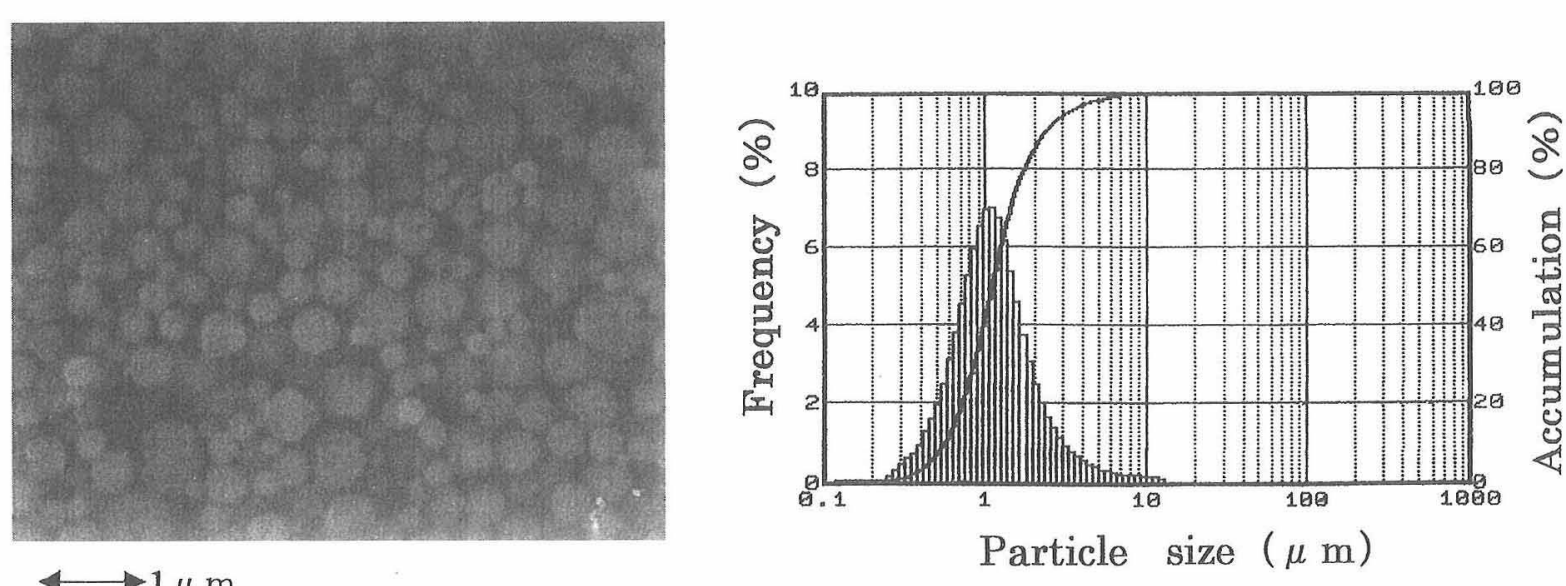

Fig. 5. SEM photographs and particle size distribution measured by microtrac laser particle size analyzer.

(a) Ni powder synthesized by WCP method, (b) Ni powder synthesized by WCP method, (c) Ni powder synthesized by CVD method.

（図 5(b)）は，CVD 法で合成した Ni 粉体（図 5(c)）と同様 な粉体物性值を持っていた。

図 6 は表 1 で示した 3 種類の $\mathrm{Ni}$ 粉体の焼成収縮率の測定結 果である. 同じ WCP 法で合成した Ni 粉体でも, 粗粒を含む 粒度分布の広い $\mathrm{Ni}$ 粉体（図中×印）は，粗粒を含まない $\mathrm{Ni}$ 粉体（図中○印）に比べて $600 \sim 1000^{\circ} \mathrm{C}$ 㫩成収縮率が小さく

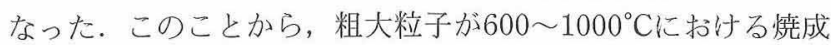

収縮率を小さくする大きな要因の一のであることが分かった. また，WCP 法による粒度分布の広い Ni 粉体（図中×印） と同じような粒度分布を持つCVD 法で合成した $\mathrm{Ni}$ 粉体（図 中@印）の場合は，更に焼成収縮率が小さくなった。すなわ ち、WCP 法では還元した Ni 超微粒子は粒子同土が相互に衝 突して粒成長する。そして，逐次還元された，一部の粒度分布 測定が困難なほどの超微粒子（0.1 $\mu \mathrm{m}$ 以下）が，ほとんど粒 


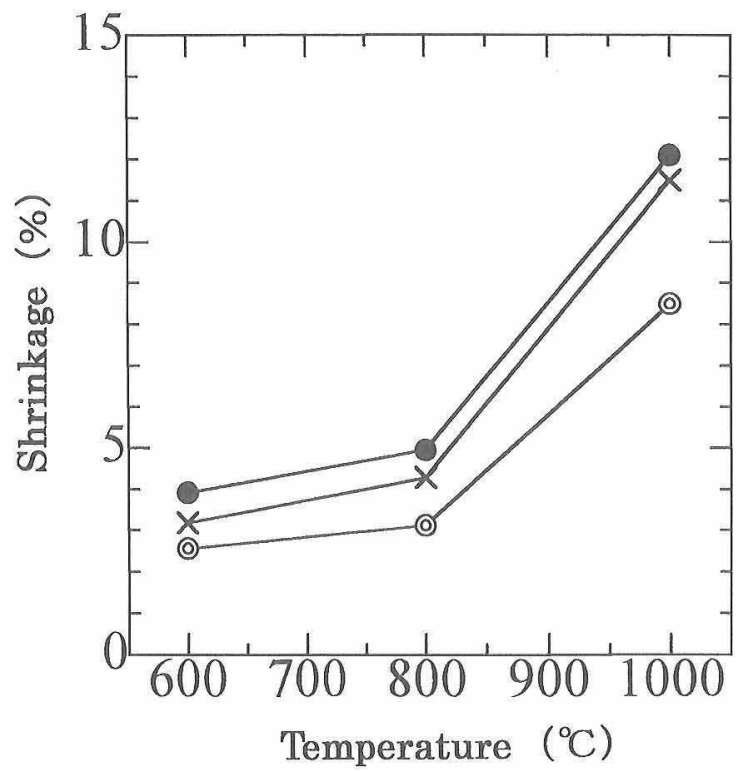

Fig. 6. Dependence of shrinkage on Ni powder properties. Ni powder synthesized by WCP method (a), $\times$ Ni powder synthesized by WCP method (b), (O) Ni powder synthesized by CVD method (c).
成長せずに反応の終結にいたると考えられる。このため, WCP 法で合成した Ni 粉体は，粉体回収技術が進展するとと もに，粒度分布測定で測定不可能な超微粒子がより多く存在す ることになる。

一方，CVD 法では気相で還元合成された超微粒子は，粒子 相互の衝突による粒成長については，WCP 法による Ni 粒子 々ほぼ同様であるが，反応終結時にそれほど粒成長が進まな かった超微粒子（0.1 $\mu \mathrm{m}$ 以下）は，飛散し装置の反応管など に付着してしまいほとんど製品としては回収されないため，超 微粒子の存在は WCP 法に比べて非常に少ないと考えられる.

このような理由から，WCP 法では超微粉の存在が 600 $1000^{\circ} \mathrm{C}$ 領域での焼成収縮率を大きくしているのではないか 上考えられる。

このことから，焼成収縮率を高精度に制御するためには，粉 体物性の正確な把握はもちろん，製法の違いに由来する何が直 接焼成收縮率に影響を与えているか，更なる詳細な検討が必要 である。

\subsection{Ni 粉体特性が焼結体表面構造に与える影響}

表 1 に示した Ni 粉体が，焼結した電極膜の表面微細構造に どのような影響を及ぼすのか SEMで観察した。その結果を 図 7 に示した。 WCP 法で合成した均一粒径の Ni 電極膜（図 7

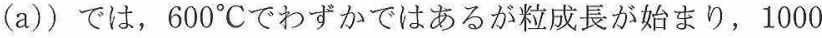

(1) $600^{\circ} \mathrm{C}$

(a)

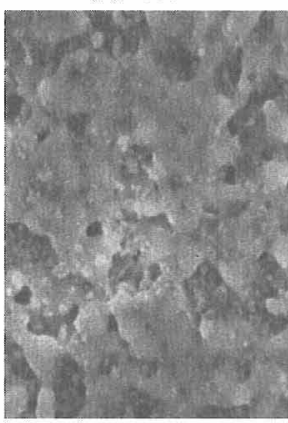

(b)

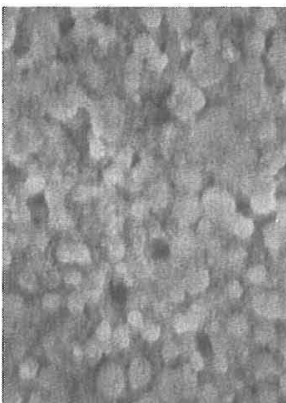

(c)

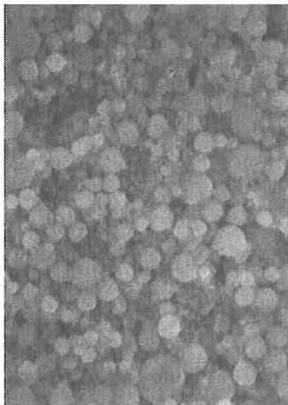

(2) $800^{\circ} \mathrm{C}$
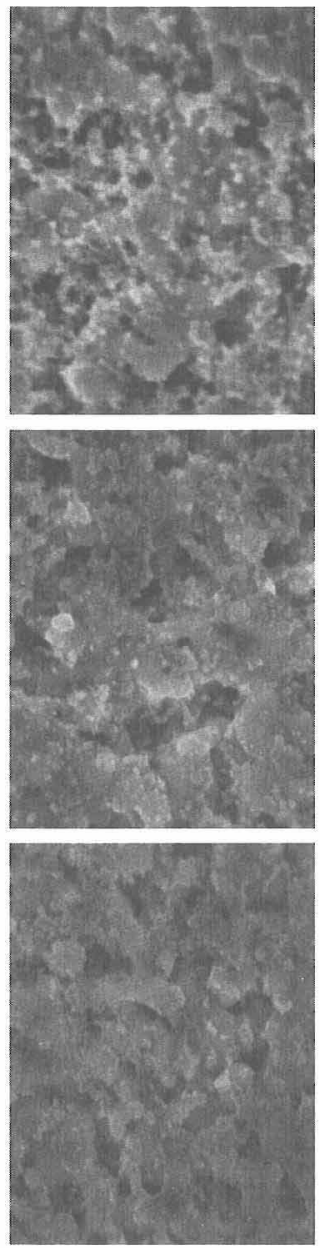

(3) $1000^{\circ} \mathrm{C}$
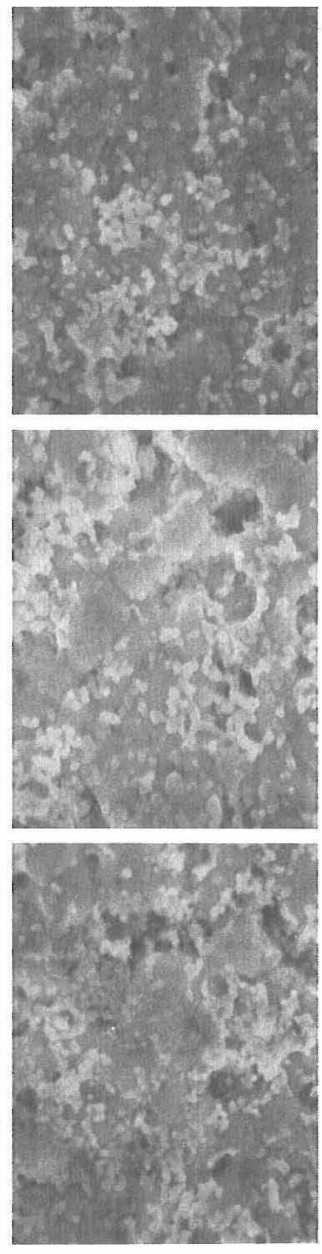

$\longleftrightarrow 1 \mu \mathrm{m}$

Fig. 7. SEM photographs of Ni electrode film sintered using various Ni powders.

(a) Ni powder synthesized by WCP method, (b) Ni powder synthesized by WCP method, (c) Ni powder synthesized by CVD method. 
${ }^{\circ} \mathrm{C}$ では，かなり粒成長が見られ緻密化していた。一方，同じ WCP 法で合成した Ni 粉体でも, 粗大粒子を含む電極膜（図 7 (b)）は， $600^{\circ} \mathrm{C}$ で $\mathrm{Ni}$ 粒子の粒成長は起きず，電極膜の緻密化 も起こってないことが観察された。これは, 先に示した焼成収 縮率と同様な結果であり，焼結がかなり抑制されていると考光 られる.

一方，CVD 法で合成した $\mathrm{Ni}$ 粉体を用いて作製した電極膜

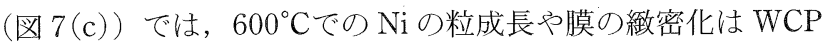
法で合成した粗大粒子を含む電極膜（図 7(b)) よりも，更に 緩慢になっている。この傾向は， $1000^{\circ} \mathrm{C}$ までの SEM 観察でも 見られ，同じ粒度分布を持つWCP 法の Ni 粉体を用いて作製 した電極膜に比べて焼結が遅いことを示している。

このことから焼成収縮率で見られたと同様に，Ni粉体の製 法の違いが $600 \sim 1000^{\circ} \mathrm{C}$ の゙の $\mathrm{Ni}$ ペースト膜の焼成面の構造に も影響を与えているものと考えられる。

\section{4. 結 論}

積層セラミックコンデンサ（MLC）に使用する内部電極ペー ストの焼成収縮率を制御する要因について, 共材 $\left(\mathrm{BaTiO}_{3}\right)$ の 分散性と $\mathrm{Ni}$ 粉体の粉体特性が及ぼす影響について検討した。 その結果以下のことが分かった。

（1） Ni ペースト中の共材の分散性の違いは，焼成収縮率を 抑制する要因として非常に重要であることが分かった。

（2）製法の異なるWCP 法とCVD 法で，粗粒の混在する ほぼ同一の平均粒径亡粒度分布をもった $\mathrm{Ni}$ 粉体の600〜1000 ${ }^{\circ} \mathrm{C}$ での焼成収縮率を測定した，その結果，CVD 法で合成した
$\mathrm{Ni}$ 電極膜は WCP 法で合成した Ni 電極膜と比較して焼結が抑 制されていた。これより, 平均粒径や粒度分布では明らかにで きない，製法による違いが600 1000ㄷに括ける電極膜の焼結 の抑制に影響を与えていることが明らかとなった。

\section{文献}

1) Burn, I. and Maher, G. H., J. Mater. Sci., 10, 633-37 (1975).

2) Sakabe, Y., Minai, K. and Wakino, K., Jpn. J. Appl. Phys., 20, Suppl. 147-51 (1981).

3) Arashi, T., Nakano, Y., Sato, A., Yamamatsu, J. and Nomura, T., J. Jpn. Soc. Powder and Powder Metallurgy, 41, 959-63 (1994).

4) Nomura, T., Satoh, A., Hitomi, A. and Nakano, Y., J. Jpn. Soc. Powder and Powder Metallurgy, 39, 590-94 (1992).

5) Nomura, T. and Nakano, Y., IEEE Tokyo Section, No. 31, 168-72 (1992).

6) Kishi, H., Okino, Y., Honda, M., Iguchi, Y., Imaeda, M., Takahashi, Y., Ohsato, H. and Okuda, T., Jpn. J. Appl. Phys., 36, 5954-57 (1997)

7) Saito, H., Chazono, H., Kishi, H. and Yamaoka, N., Jpn. J. Appl. Phys., 30, 2307-10 (1991).

8) Armstrong, T. R., Young K. A. and Buchanan, R. C., J. Am. Ceram. Soc., 73, 700-06 (1990).

9) Ueyama, R., Ueyama, T. and Koumoto, K., J. Ceram. Soc. Japan, 108, 769-73 (2000) [in Japanese].

10) Ueyama, R., Ueyama, T., Koumoto, K. and Kuribayashi, K., J. Ceram. Soc. Japan, 109, 344-47 (2001) [in Japanese].

11) Ueyama, R., Seki, N., Kamada, K., Harada, M. and Ueyama, T., J. Ceram. Soc. Japan, 107, 652-56 (1999) [in Japanese].

12) Ueyama, R., Seki, N., Ueyama, T. and Koumoto, K., J. Ceram. Soc. Japan, 108, 661-65 (2000) 